\title{
Dualism in the South Halmahera Government's Policy on Managing Diversity in the Bacan Sultanate
}

\author{
Flavius Floris Andries \\ Institut Agama Kristen Negeri Ambon, Indonesia \\ Email: qumran_2007@yahoo.com
}

\begin{abstract}
The issue of dualism in the South Halmahera government policy on managing cultural diversity in the Bacan Sultanate is an interesting phenomenon to study. Saruma, the multicultural icon used to manage diversity in the Bacan Sultanate, is not reflected in governmental policy or society, in general. This study focused on three research questions: 1) What is the socio-historical context of the Bacan Sultanate from which the concept of Saruma emerged? 2) Why has the South Halmahera government failed to apply the concept of Saruma in its policy on managing diversity? 3) What are the impacts of this dualism on the people? This qualitative research employed observation techniques to understand the community's dynamics. In-depth interviews were conducted to obtain data concerning the people's social lives as well as the government's policy and its impact on society. A literature review was undertaken to understand related research and to formulate a theoretical framework as an analytical device. The results showed that in spite of the cultural authority owned by the Sultanate, the absence of political authority has led to a failure to implement its Saruma concept in managing the cultural diversity. The change of political system from representation to participation has also led to transactional politics, which benefits the majority but disadvantages the minority, and the traditions of domination and hegemony, in turn, have discriminated against the minority, endangering their identity.
\end{abstract}

Keywords: Bacan Sultanate; civil servant uniforms; dualism in government policy; Saruma culture; school uniforms; South Halmahera government

\section{BACKGROUND}

A multicultural society, if it is not managed well, can often give rise to discrimination, conflict, and violence. Religious and ethnic identities are the two multicultural elements that may bring about various social problems. This statement is supported by several studies showing that in the last two decades, tensions between different religious and ethnic identities have triggered discrimination, conflicts, and violence in many regions in Indonesia (Mas'oed, 2000; Betrand, 2004; Mujiburahman, 2006; Achmad, 2019). This is a consequence of identity contestation as an unavoidable phenomenon in society.

An-Na'im explains in his book "Islam and the Secular State (2008: 225) that Indonesia, as a multicultural country, is facing a fundamental challenge to implement what they call the "nation-state model," made more problematical, because of potential coercions to comply to an artificial uniformity imposed by the authorites, or by certain groups over other groups. An-Na'im's statement is a description of an existential ideological war in Indonesia. Despite the demands of Islamic leaders not being agreed to insert state acknowledgement of adherence to syariah law by Muslim in the Jakarta Charter, the struggle for greater Islamic ideological influnce is ongoing.

Ideological wars as a multicultural phenomenon in Indonesia is not only a part of the nation's history, but also a political state dynamic that exists til now at both at the national and local levels, when religion and politics integrate to become a force for political power. 
This can be seen in the emergence of various religious parties on both the national and local political stages. In the local political context in South Halmahera, the Bacan Sultanate that governs the region was tolerant and inclusive to the other ethnicities and communities since the inception of "Saruma tradition." However, since the Social Justice Party (Partai Keadilan Sejahtera-PKS) came into power with an ideology : 1) that draws on Islam as a solution to national and state life. 2. Sees a transformative power in Islamic teachings and values in rebuilding the people and the nation in all sector. 3 . The power of Islam pioneer and build cooperation with others but at the same time enforcing an Islamic system and its values bless the universe. 4 . The accelerator in making civilian society in Indonesia. There are some historical facts to support the opinion, for example, that a Christian state flag raiser should wear a veil (Andries, 2019: 10), students and civil servants must wear Islamic uniforms, and other government policies. ${ }^{1}$

The above description shows the social context of South Halmahera, particularly the Bacan Sultanate. On one hand, Bacan, with its cultural concept of "Saruma," seeks to maintain the diversity existing in the society. On the other hand, several government policies tend to be intolerant toward minorities. Therefore, the problem to be addressed in this research is place of the Saruma tradition to maintain the diversity in the Bacan Sultanate in South Halmahera. This research raises the issue of the dualism of the government's policy in managing diversity in the multicultural context of South Halmahera. The research questions are: 1) What is the socio-historical context of the Bacan Sultanate from which the Saruma concept emerged? 2) Why has the South Halmahera government failed to apply the concept of Saruma in its policy for managing the existing diversity? 3) What are the impactsof this dualism?

It is important to discuss the three questions in this article because diversity, on one hand, is the wealth and strength of a nation to raise a sense of togetherness. When badly managed, on the other hand, it triggers conflicts and violence that tear at social cohesion. In other words, diversity potentially makes adivison between the majority and the minority where the majority exercise cultural domination and hegemonic. The majority, in sociopolitical terms, is stronger than the minority making for a phenomenal identity problem and an important object of research.

\section{RESEARCH METHOD}

The research took place in the Bacan Sultanate, South
Halmahera District, North Maluku Province in 2018. To answer the research questions listed above, a qualitative method with various techniques was used. An observation technique was used to understand the dynamics of people's live in the Bacan Sultanate. In-depth interviews with some politicians from the political parties (Partai demokrasi Indonesia perjuangan, -PDIP, Partai Gologan karya-Golkar, partai nasional Demokrat-Nasdem), Partai Keadialn Sejahtera-PKS, and Partai Persatuan pembangunan- $P P P$ ) were used to collect information on their views and responses to the local government's Sharia-based policy on uniforms for schools and for female civil service employees. Another source who was interviewed included the Secretary of Education of the South Halmahera District whom the Vice regent (wakil Bupati) had recommended. The data needed was the background the in determining a policy on uniforms. Teachers and students were also interviewed for confirmation. Religious leaders, Muslim and Christian, were questioned about managing diversity. The data were analyzed using a cultural studies approach to investigate and criticize social facts and the ideology behind every policy in relation to the study of identity politics from which domination a rises, the hegemony that creates discrimination against minority groups's rights.

\section{FINDINGS AND DISCUSSION \\ Bacan Sultanate and Multiculturalism}

The Bacan Sultanate has long been an area with different ethnicities and tribes. According to an interview with one informant, the Bacan Sultanate consists of various tribes and Bacan has become an inclusive sultanate. In the 1800s, Sultan Gahral Ardiyansah invited people from Sanger, Maluku Tenggara, and Ambon to cultivate its soil and to teach agricultural techniques. The Sultan gave them a place to live and treated them the same as the natives. This informant said that the Sultan had a philosophy that let Islam, Christianity or other religions alone, believing that even ants were his people. This shows that the Sultan treated all people the same and if there were any problems, they would be discussed together. This is a form of accommodative politics implemented by the Sultan showing how he led lead of his people. ${ }^{7}$

Based on recent data, the Bacan Sultanate consists of 20 ethnicities. According to one of the palace's figures, the current Sultan always respects and protects all of his multicultural communities. This Sultan, who is a pious Muslim, has given land to his Christian communities to build a church in the Bacan area nearby the palace 
(Labuha) ${ }^{8}$ Historically in Labuha there has existed a mosque, a Christian church, a Catholic church, and a Pentecostal church.

The Bacan Sultan, since long ago, always respects diversity or multiculturalism. The arrival of Christian communities is respected and they were even given land to build a place to pray. The Christian and Catholic churches in Labuha were built during the colonial era. ${ }^{9}$

It is seen that the Sultan, as a political and cultural leader at the time, ran what would be called in modern terminology (Taylor, 1994) "a multicultural policy" that highlighted the aspects of cultural recognition, equality, and equity towards the other identities in the Bacan Sultanate. Despite minority status, Sanger and Ambon were given spaces and places to show their identity and existence as Christians. Here, the Sultan, as a political and cultural leader at the time, truly understood the Islamic values that respect human rights (QS 5: 32) and other religions (QS 2: 256). The Sultan's policy is an appreciative form of religious freedom. This is what Rahman says about the essence of human rights according to Islam as a high appreciation of the value of equality (Rachman, 1980:45). The existence of churches in the Sultanate palace is evidence of the implementation of Islamic values and this also shows the multicultural policy implemented by the Sultan. This is similar to Farelly 's view (2004:43):

Multiculturalism is not about difference and identity, but about those that are embedded in and sustained by culture, that is a body of beliefs and practices in terms of which a group of people understand themselves and the world and organize their individual and collective lives.

In other words, multiculturalism emerges as a response to the fact of diversity in society (Karengga, 1997: 196; Heywood, 2002: 119). This is what appears in the Bacan Sultanate in South Halmahera. The purely Islamic identity of the Sultanate when faced with other religious identities in a diverse context embraced inclusiveness. Accordingly they can live together peacefully and share the same "Sultanate" space.

\section{South Halmahera in the Context of Political Election: From Representation to Participation}

The change to a post-New Order political system in Indonesia, from representation to participation, led to transactional politics as the individual had complete and full rights to choose political affiliation. This political system is intended to strengthen democracy at the local government level and to ensure equality of citizen rights in safeguarding and strengthening national democracy (Raharusun, 2017: 7). According to Rousseau, the concept of participation in democracy emphasizes individual participation in the political process (Mariana, 2017: 90).

Identity politics, in this context, would thrive and turn into a political device. It does not mean that identity politics in Indonesia is a new phenomenon. Romly stated that although suppressed by the authoritarian government, ethnic and religious, even tribale or regional, identities had colored the history of politics and democracy in Indonesia (Romli 2019: 79). As the regime in power and politics changed, the political system. And identity politics, both ethnic and religious, became elements of political power that were made use of in both national and local contests. According to Romli, ethnic and religious identities are two forces that have carried politicians to success (Romli, 2019: 86; Yusuf et al. 2015: 15-26).

The political success of PKS in the local political stage in South Halmahera exemplies the power of ethnicity and religion discussed. The ethnic identity politic returned a religion-based party as the winner of the local political contestation. Ideologically, PKS declares itself as a preaching party that struggle for Islam as a solution for life. This has become a transformative power to accelerate the implementation of Islamic values and teachings in Indonesian civil society that embraces cooperation with those of like mind in order to strengthen Islamic values and a system that is rahmatan lil alamim (beneficial for all) as. ${ }^{10}$ This vision of PKS accords with the statement of an informant, $\mathrm{H}$, from the PKS party who said that the vision of PKS is developed on a religious and nationalist basis and that the ideology of rahmatan lil alamin (beneficial for all) is foundation. ${ }^{11}$

This ideology becomes an umbrella for the party system at both the national and local level. Under the ideology of Islam, PKS interacts with society in the form of proseltyzation. This party has five supporting elements: the Indonesian Islamic Proseltyzing Council (Dewan Dakwah Islamiyah Indonesia -DDII), Campus Prozeltyzing Institution Activity (Aktivis Lembaga Dakwah Kampus -LDK), Alumni of Middle-East Higher Education, and Pesantren Alumni. Those elements work hand in hand to strengthen PKS role and function. In order to implement the party's strategy and to enter the parliamentary system, PKS promotes a clean parliamentary issue and is in favor of society's interest. ${ }^{12}$

An informant in South Halmahera stated that 
the PKS jargon "clean, caring, and professional" is catchwords to implements the concept of rahmatan lil alamin in the context of party and parliament. ${ }^{13}$ This jargon enables politicians a chance to attract members of non-Islamic communities to join PKS as legislative candidates. Basyir recorded that in 2004, PKS accommodated more than 30 non-Muslim candidates and PKS also recruited non-Muslims as members. This is shown in the inauguration of the PKS Regional Executive Council (dewan pengurus daerah-DPD) in Piniai on June 5, 2002 in which the members were mostly Christians. Moreover, PKS also gave a chance to Hindus to become legislative members through the National Consultative Conference (Musyawarah kerja nasional -MUKERNAS in Bali (Basyir Ach, 2014).

In its political contestations, PKS with its religious ideology became more and more pragmatic in order to achieve power and authority. The ideological borders became less clear when all the parties were competing to win the regional heads of Government election (pemilihan kepala daerah -PILKADA). This strategy of widening its appeal to non Muslim voters was successfully applied so even though PKS is based on Islamic ideology, it received much support from non-Muslim voters. However, when it won the political fight and received power and authority, the spirit and motivation of its Islamic ideology return manifesting itself in its approach to cultural diversity. This situation happened in South Halmahera. Winning the game is the target. Then, to achieve the target it is acceptable to use all capital including symbolic capital such as the concept of the Tobelo-Galela tribes. But, after winning the game, the arena is changing. This is what the non-Muslims felt who had previously voted for the PKS candidate for local leader and other political actors from Islamic based parties. The implementation of policy does not consider the philosophy of "Saruma" that hads been the main conceptual drivers of the Bacan Sultanate in managing diversity. They PKS has instead implemented a religious based policy. This phenomenon, in Bourdieu sociological concepts (2002: 109-110), is called a strategic game in an arena which results in and results from a habitus of the party dynamic or the political actors. As Bourdieu said (2010:72; 1993:44), the dynamic sociological context in the governmental political system shows the dynamic habitus. This habitus, which results from and results in, is highly dependent on social life and the structure that structures and is structured by its social world. Praxis and the consequence of the dynamic habitus in a political struggle is described by the following informant's statement:

The Islamic actors that we voted for in the local election do not care about or pay attention to the Christians' interests after winning the political arena in the local election. ${ }^{14}$

This statement reflects disappointment towards political practices in South Halmahera. The strategic game and the dynamic habitus finally showed a negative image, as an informant states:

That's enough in three periods of local leader elections we chose regents from the PKS party who are, in fact, fanatical. ${ }^{15}$

The disappointment in the political choice is a consciousness that emerges from a changed sociological reality, an awareness of a fanaticism because PKS policies do not accommodate all social groups.

PKS success in winning three successive election is an interesting phenomenon, while other Muslim polical actors or candidates, although supported by other Islamic or nationalist parties, lost and could not compete with those from PKS. Catchwords such as "justice", "welfare", "clean", "caring", and "professional" disappear with the rise of partiality towards certain religious identity groups, as stated by the above informants. The arena structure changed again where partiality was no longer felt by nonMuslim voters. This Corresponds to Bourdieu's Theory (1993:44) about arena dynamics, that they always change and are determined by the position of the agent. In other words, before winning the game, an agent should be able to accommodate all political instruments, but when achieving power the authoritative structure the power structure determine the course. The economic, social, and cultural capital are in the ruling party's hand, thus the structure of the is structured by this agent.

\section{Dualism in the South Halmahera Government Policy on Managing Diversity after the New Order Era}

\section{Saruma Culture as a Symbol of Unity in Diversity}

After the New Order era, there have been several ethnic and religious conflicts in Indonesia such as in Poso, Sambas, Maluku, and many other places (Maso'ed, 2000; Betrand, 2004; Mujiburahman, 2006, Kadir, 2019).This also happened in Bacan South Halmahera. Christian communities evacuated from Bacan to an evacuation area to save themselves from the conflict. Moreover, all churches in Labuha, the Sultanate area, were destroyed and burned. An informant shared information in an interview that these people were evacuated by a warship to Seram Island in Maluku province. ${ }^{16}$ 
After tensions abated, Christian communities finally went home to Bacan andworked to re- establish their socio-religious and cultural lives. Churches were rebuilt and social activities were back to normal. Together with the government of South Halmahera and the cultural leaders, the people of Bacan made a new agreement called "Saruma" culture. An informant who is part of a noble family said:

Saruma culture is a social identity of the Bacan Sultanate society that has actually existed since a long time ago. This culture was already developed by Sultan Gahar by inviting many people from Sanger, Ambon, and Saparua to work in Bacan, and the Sultan provided them a place to live in the area of the Sultanate. This has inspired the government of South Halmahera and the Sultanate to bring back the spirit of togetherness and live peacefully with Christian communities after the conflict, and make it the identity of the Sultanate and the South Halmahera government. ${ }^{17}$

The informant acknowledged that Saruma culture, which means living in one house or living together, is a heritage that was created long ago by previous Sultan and this culture is trying to revive after the conflict to strengthen the socio-cultural cohesion of the South Halmahera society. At the same time, this culture also becomes their identity. This Saruma culture confirms that both the Sultanate and the Muslim in society should be accommodative and tolerant to the Christians.

The Saruma culture also relates to the Tobelo-Galela, the dominant tribes in South Halmahera. In both tribes, there are Muslims and Christians. The Saruma culture is a form of social capital that bonds different ethnicities and religions in the Bacan Sultanate. Putnam discusses that social capital in the form of various integrated social groups may result in a civic engagement that determines social stability and government effectiveness (Putnam, 1993: 163-169). Thus, the Saruma culture is a form of civic engagement as well as social capital for the Bacan Sultanate communities to live together in diversity. The role of the Bacan Sultanate in reviving the Saruma culture after the conflict was significant. As cultural agents, they have a stake in growing a new order of life in the heterogenous society post conflict. This is in keeping with what Varshney (2002: 3) says about the important role of communtiy leaders or figures to prevent conflict escalation between Hindus and Muslims in India. In South Halmahera, the cultural concept was chosen and adapted by the local government in managing social life, although finally the Saruma culture has become only political window dressing for the government because the cultural values of this culture do not appear in its recent policies.

\section{Uniformity of Culture in Policy in Formal Institutions}

After the New Order era, the government formulated a new policy regarding school and office uniforms. All students from elementary school to senior high school should wear long sleeved shirts for boys and girls, long skirts for girls, and trousers for boys. The same policy applied to civil servant, including for teachers.

According to information from an informant, the use of Islamic-nuanced uniforms, based on the instruction by the local education department, had to be strengthened by an official rule to legitimize the policy. ${ }^{18}$ But, according to the Secretary of the local Education Department, there is no official rule with regard to uniforms. ${ }^{19}$ Therefore, there is a controversy between the two sources of information. This shows that there is something hidden by the civil apparatus. The Secretary promised to give physical proof of the uniform regulation, but until the end of this research, he never fulfilled his promise while offering many reasons and saying his staff was preparing it. ${ }^{20}$ Another example is the rejection by the Vice Regent, one of the policy makers, to be an informant for this research. This kind of attitude leads to a judgement that there is an effort to hide the social fact of a multicultural phenomenon in South Halmahera society. One of the facts of the government policy in South Halmahera, which is indicated of fanaticism and intolerance to minorities, is to force female Christian students who take a part in the national flag raising ceremony, to wear a hijab (Andries, 2019: ). This exclusory attitude of the government toward minorities can be seen in the following informant's words:

When the minority groups sought financial assistance from the government, the government often responded negatively. The proposals for financial assistance by minority groups are often rejected. Based on the information of a politician, when a certain religious organization made a proposition for financial assistance of the government, the regent agreed in the beginning, but then when the proposal was made to the treasurer, he said there was no money. ${ }^{21}$

This information shows that the social arena in South Halmahera, specifically in Bacan, subordinates the minority position and their rights to access public services do not become priorities. Minority groups become a second class community treated unequally 
by the state. According to Taylor (1994), this is a form of denial of the minority's existance that can be called unrecognition, inequality, and inequity. Therefore, $s$ characteristic of public service in the social political arena of South Halmaherais that it does not support the concept of multiculturalism. In fact, it shows rulling groups domination and hegemony that represent symbolic violence (Bourdieu, 1995:164).

The governmental arena in South Halmahera shows the power of the majority as dominant group run by the state that results in a minority being repressed. The minority groups in South Halmahera exist in seen in its control of a community where it receives unequal treatment from the state when compared to the majority. This domination and hegemony by the government works against the democracy dynamics foughtfor by reformation activist. An informant says: ${ }^{22}$

Discrimination and intolerance that the minority felt in the social political context has already happened since the area expansion and at the same time, the change of political system with one man one vote was implemented. When PKS won the election and had control, the government policy seems to sacrifice the minority.

The opinions and information provided by the informants indicate that the government subordinates minority interests, so discussion on the state's religion and nationalism have been the focus of attention. The identity politics in this situation are hard to execute. The majority exercises dominanance and will always try to maintain power, in this situation identity politics of the minority gains little traction, so discrimination will color multiculturalism in Bacan. In his book "Religion State and Secularism" (2008:256), An-Na'im says that the problem of discrimination is not only about the implementation of Sharia, but also about structural changes at the lower level. The policy endorsement of local autonomy in 1999 adds complexity to the situation since the policy has given a space to the local community to implement Sharia at the regency and province levels. Therefore, the multicultural phenomenon should not only be analyzed in the local context, but also in the national and global contexts.

PKS has emerged as a solid party and it successfully uses opportunities to gain support from the people with its ideology that seems open or inclusive. This party won democratic election in several areas and thus, the Sharia movement was strengthened in several areas, including South Halmahera. After the area expansion and South Halmahera became a regency (kabupaten), PKS won the regent (bupati) and legislative elections three times in row.
Hence, in the local government level in South Halmahera, the PKS vision on Sharia has become a priority program that must be implemented.

\section{Government Discrimination in the Public Services}

The social problems that involve religious identity are serious phenomenal problems in Bacan. Relationships between young men and women of different religions is an ordinary thing that happens in social life and is human rights. Religion cannot even prohibit this, but if it does intervene, it can be characterized as a suggestion based on ethical consideration, rather than legitimation:

It is often found in the relationships between young men and women of different religions that the women may fall pregnant. If the man is Muslim and the woman is Christian, but the man does not want to take responsibility for the woman's pregnancy, even though the case is reported legally, the Muslim man always gets relief and ultimately is not subject to any legal action. The woman's side and her family become the victims. Alternatively, if the Muslim man takes the responsibility to marry the Christian woman, then the Christian woman needs to convert to Islam. In contrast, if the man is Christian and the woman is Muslim and the man does not want to take the responsibility for the woman's pregnancy, the man will be given customary fines of Rp. 500.000 .000 or failing this, he will go to jail. ${ }^{23}$

This information shows discrimination by the government. This is confirmed through information by an informant. He said that his friend, a Christian man, finally converted to Islam as a way to avoid being punished with a 500 million rupiah fine or jail sentence because he impregnated his girlfriend, a Muslim woman. ${ }^{24}$

Pre-marital sex is not ethical according to many many religions and traditions and prohibit it. However, in similar cases from Bacan, the way to solve the problem is a fact that shows how the police or any related law officers are not neutral. Thus, for Christians in Bacan, they see the phenomena punishment against Christian man as a large Islamization agenda that runs slowly. Moreover, if a Christian converts to Islam, it will be an honor for Muslims, as an informant says: ${ }^{25}$

I got a letter from MUI (Indonesian Ulama Council) that explains that a Christian had recited syahadat. In my opinion, religiousity is related to human rights, so I don't think I should respond to 
the letter. I think the church also did not want the letter because the matter of embracing religion and converting is a private matter, and institutionally the church has no right to intervene.

A young informant explained this conversion and MUI sending the letter to the church as being a consequency of out of wedlock pregnancy with a fines was to avoid fines of as much as 500 million rupiah. If the man could not afford it, he would be jailed, without considering the case asone of love and liking each other, so finally the man chose to be a muallaf (convert to Islam). ${ }^{26}$

It can be seen from the data presented above how an authority uses certain capital by the majority. Regardless the ethicality the case, it shows how the majority has used itscapital, economic, social, cultural, and symbolic, to repress the minority. MUI, Sharia, law enforcement, and the 500 million rupiah fine are economic and social capital in Bourdieu's terminology, and a symbol capital of the majority's power. This subdued the minority and they became powerless with little choice but to convert to Islam and marry. In short, marrying is a form of responsibility for the action and becoming a muallaf is a strategy to avoid both legal and customary sanctions although there is no violation of law in the case. From Bourdieu, perspective this phenomenon is called strategy and trajectories. Strategy is understood as a practice with a certain orientation. As a product of habitus, strategy is an unconscious disposition and is dependent upon the position of the agent in the arena and upon the problem underlain the confrontation. Strategy builds the fight form of fight and the orientation of the solution. Trajectory is viewed as the result of a struggle and an effort to achieve symbolic capital in the arena and is observable through a network of relation, economy, culture, and society (Bourdieu, 2002: 109-110).

From the state's viewpoint, the government has handled the multicultural issues well and wisely because they acted in favor of the majority, so they view that they have enacted justice for all people. In fact, the government, as the state's representative, appears to be submissive and in favor of the interests of the majority group and has lost its independency and authority. Migdal (1998) says the state is in a weak situation meaning that the state function of social control keeps running through the law, but intervening with and penetrating society is a form of playing the process for the majority's interests. In Migdal's terminology (cf. Bourdieu, 1998:33), what is meant by majority is a certain group of civil society that has authority in the society (MUI).

Looking at the portrait of multicultural phenomena in South Halmahera, particularly in Bacan, a strong state existence and authority is required. Citing Fukuyama (2005:38), the strong management, organizational, political, cultural and structural systems become urgent. Fukuyama's concept is similar to Bourdieu's concept (in Jenkins, 1992: 84-88) about any capital, whether social or cultural. Fukuyama's point about the cultural aspect (keraton or Sultanate) or a kind of capital in Bourdieu's terminology in the context of South Halmahera and also the multicultural condition of the regency should be considered by the South Halmahera government in making policies or regulations. This is also confirmed by Migdal (2001:47-53) that society does not consist of a single entity, but various identities and cultures.

\section{CONCLUSION}

The following conclusions can be made from this analysis of dualism in the policy of South Halmahera's government on managing diversity in the Bacan Sultanate.

Firstly, multiculturalism is a factual social phenomenon that needs serious attention, although scientists claim that there is social power and capital in the management process of a flourishing, superior, and wealthy nation (Mahfud, 2009: 170). In fact, however, multiculturalism is a threat for management. This has manifested on global, national, and local levels. In the US, when the government issued racial policies that suppressed black people, Antony Richard (1995: 23) wrote in The Color Problem that, "The color problem is that it distinguishes one race from the other, when people establish social and psychological barriers, termed as color-bar, consisting of prejudice, racial-discrimination, and racial segregation." Richard's statement confirms that racial policies lead to domination and hegemonic practices that manifest themselves in intolerant behavior, enacted by the majority onto the minority (Goldberg, 1995: 5; Glazer: 1997: 34). A multicultural-phenomenonaffected policy, as scientists describe its occurrence globally, is also found in Indonesia at both the local and national levels, which discriminates against minorities such as Ahmadiyah, Sundawiwitan, Kaharingan, and others (Andries, 2014; Mulia, 2009; Pichard, 2011).

Secondly, the analysis confirms the threat of intolerant practices caused by this multicultural phenomenon. In Indonesia, ethnic and religious identities in the post-New Order era are often harnessed for political ends. This is precisely what the politicians in South Halmahera did. Interestingly enough, these politicians did not seem to take the spirit of local-based ethnicities into account when governing and formulating local policy, instead the religious Sharia dominates. These 
developments are in accordance with Bourdieu's concept that arena, strategy, and capital lead to habitus.

Thirdly, utilizing ethnic and religious identities in political contests leads to inherent risks in formulating policies, and moreso, in a multi-identity, pluralistic nation. The transformation in politics from representation to participation forces the practice of transactional politics to rise. This new system significantly benefits the majority for transactions, giving political parties and their constituents bargaining power. To enhance ability, agreements or transactions should be considered. This was what the Social Justice Party (or PKS) did in South Halmahera, where Muslims are the majority. After winning in the local election, PKS applied Sharia-based regulations. This confirms Bordieu's dynamic concept of habitus and trajectory. This research showed that habitus, capital, strategy, and trajectory are urgent forms of power for every politician.

Fourthly, in a transactional political system, politicians will obtain significant votes if they prioritize a certain group's interests. Consequently, the politics of identity become stronger and turn into domination and hegemonic practices that discriminate against the minority. This, in turn, is manifested in the form of intolerance in every policy and threatens diversity management locally and nationally. In the end, multiculturalism, which, according to Farelly, is not a threat and should not be a problem, becomes a never-ending problematic situation. This study has also given a better picture of the minority, which always initiates the practice of tolerance.

\section{ENDNOTES}

1) Interview with informant initial E, August, 2018

2) Interview with informant initial $\mathrm{H}$, August, 2018

3) Interview with informant initial T, H, August 2018

4) Interview with informant initial $\mathrm{H}, \mathrm{T}, \mathrm{Z}$, August, 2018

5) Interview with informant initial, $\mathrm{H}$, August, 2018

6) Interview with informant initial T, August, 2018

7) Interview with Informant initial H, T, August, 2018

8) Interview with Informant, initial H, August, 2018

9) Interview with informant initial H, August, 2018.

10) Interview with informant initial $\mathrm{H}$, August, 2018

11) Interview with informant initial H, August, 2018

12) Interview with informant initial N, August, 2018.

13) Interview with informant, initial J, August, 2018.

14) Interview with informant initial J, P. August, 2018.

15) Interview with informant Initial T, August, 2018.

16) Interview with a member of educational Institution,
August, 2018

17) Interview with the Secretary of the Local Education Department, August, 2018

18) Interview with the Secretary of the Local Education Department, August, 2018

19) Interview with GMKI member, and religious figure, August, 2018

20)Interview with Informant initial, Y, W, August, 2018

21)Interview with informant initial G, August, 2018.

22)Interview with Informant initial, N, August, 2018.

23)Interview with informant initial J, August, 2018.

24)Interview with informant initial W, August, 2018.

\section{BIBLIOGRAPHY}

Ach. Basyir (2014). Ideologi Politik Dilematis Partai Keadilan Sejahtera (PKS) antara Gerakan Tarbiyah dan Pragmatisme. IN RIGHT: Agama dan Hak Azazi Manusia, 3(2), 237-258.

Achmad Mukhsin (2019). A Hermeneutical Analysis on Fatwa of the Council of Indonesian Ulama Dealing with Discriminating Shia in Indonesia. Madania, 23(1), 33-46. doi: 10.29300/madania.v23i1.1751.

Andries, Flavius Floris (2019). Politic of Identity: Between Conflict and Compromise to Construct the Social Identity: Case Study toward the wearing of hijab by the Chrsitian women studies while Serving as paskibraka in Halmahera Selatan. Proceding International, Gender and Women Studies. theicrd. org/pdf.GWS2019.

Andries, Flavius Floris (2014). Minoritas Dalam Masyarakat Majemuk: Pengelolaan Keragaman Agama Di Indonesia Pasca Orde Baru. Dissertation. Yogyakarta: UGM.

An-Na'im Abdullah Ahmed (2008). Islam And The Secular State. USA: Harvard University Press.

Betrand, Jacques (2004). Nationalism and Ethnic Conflict in Indonesia. USA: Cambridge University Press.

Bourideu Pierre (1993). The Field of Cultural Production: essays on Art Literature. Cambridge: Politiy Press.

Bourideu Pierre (2002). Distinction: A Social Critique of the Judgment of Taste. Cambridge: Harvard University Press.

Bourideu Pierre (2010). Outline of a Theory of Practice. Canbridge: Cambridge University Press.

Farrely Collin (2004). Contemporary Political Multiculturalism. London: Sage Publication.

Fukuyama Francis (2005). State Building: Governance and World Order in the Twenty First Century. USA: Cornel University.

Goldberg, David (1995). The Multiculturalism: A Critical Reader. Cambridge: Blackwell Publishher Inc. 
Heywood, Andrew (2002). Multiculturalism. In Politics, Second Edition. New York: Palgrave Foundations.

Jenkins Richard (1992). Pierre Bourdieu. London: Routledge. Kadir Hatib Abdul (2019). Hierarchical Reciprocities and Tensions between Migrants and Native Moluccas Post-Reformation. Journal of Southeast Asian Human Rights, 3(2), 344-359. doi: 10.19184/jseahr. v3i2.8396.

Karengga, Maulana (1997). Black and Latino Relation: Contents, Challenge and Possibilities. In Reed (Ed.), Multi-America: Essays on Cultural Wars and Cultural Peace. Penguin Books.

Mariana Dede and Luthfi Hamzah Husin (2017). Democracy, Local Election, and Political Dynasty in Indonesian Politics. Wacana Politik, 2(2), 88 - 97.

Maso'ed Mohtar (2000). Kekerasan Kolektif, Kondisi dan Pemicu. Yogyakarta: P3PUGM.

Mahfud Choirul (2009). Pluraisme, HAM, Demokratisasi dan Civil Society: Menggugat Tanggungjawab Negara dan Agama-Agama. In Prospek Pluralisme Agama di Indonesia. Yogyakarta: Institut Dian Interfidei.

Migdal Joe (1988). Strong and Weak State: State-Societies Relations and State Capabilities in the Third World. Princenton: Princenton University Press.

Migdal Joe (2001). State in Society-Study How State and Societies Transform and Constitute One Another. USA: Cambridge University Press.

Mujiburahman (2006). Feeling Threatened: MuslimChristian Relations in Indonesia's New Order. Amsterdam: Amsterdam University Press.

Mulia Siti Musda (2009). Potret Kebebasan Beragama dan Berkeyakinan di Era Reformasi, dalam Merayakan Kebebasan Beragama. Jakarta: ICRP.

Picard Michel and Madinie Remy (2011). The Politics of Religion in Indonesia. USA and Canada: Routledge, Abingdom.
Putnam Robert (1993). Making Democracy Work: Civic Tradition in Modern Italy. Princeton University Press. Romli Lili (2019). Political Identity and Challenges for Democracy Consolidation in Indonesia. Politik Indonesia: Indonesian Political Science Review, 4(1), 78-98. doi: 10.15294/ipsr.v4i1.17214

Rachman Faslul (1980). Major Themes of the Qur'an. Minneapolis and Chicago: Bibliotecha Islamica.

Raharusun Anthon (2017). Local Election and Reinforcement Democracy in the Indonesian State System. Papua Law Journal, 2(1), 1-25.

Richard Anthony (1995). The Color Problem. Baltimore: Penguins Books.

Sholahudin (2006). Ide Penerapan Syari'at Islam PKS pada Pemilu 1999 \& 2004 serta Respon Non-Muslim \& Aktivis Jender (Studi Kasus PKS DIY). Thesis. Yogyakarta: CRCS UGM.

Taylor, Charles (1994). Multiculturalism: Examining the Politics of Recognition. Princenton, New Jersey: Princenton University Press.

Varshney Ashuthos (2002). Ethnic Conflict and Civic Life. London: Yale University Press.

Wasino, et.al. (2019). From Assimilation to Pluralism and Multiculturalism Policy: State Policy Towards Ethnic Chinese in Indonesia. Paramita: Historical Studies Journal, 29(2), 213-223. doi: 10.15294/10.15294/ paramita.v29i1.20869

Yusuf, Ihsan Idris et.al. (2015). Ethnic Contestation in Regional Extension: Local Elite in Pringsewu Regency, Lampung Province, Indonesia. International Journal of Multicultural and Multireligious Understanding, 2(1), 25-31. https://dx.doi.org/10.18415/ijmmu. v2i1.10

Zachary Abuza (2007). Political Islam and Violence in Indonesia. London and New York: Routledge. 